\title{
"The Importance of Work-Life-Balance"
}

\author{
${ }^{1}$ Ms. S. Pattu Meenakshi, ${ }^{2}$ Mr. Venkata Subrahmanyam C. V., \\ ${ }^{3}$ Dr. K. Ravichandran \\ ${ }^{1}$ Research Scholar, Department of Management Studies,Madurai Kamaraj University, Madurai - 625021 \\ ${ }^{2}$ Research Scholar, Department of Entrepreneurship Studies,Madurai Kamaraj University, Madurai - 625021 \\ ${ }^{3}$ Professor \& Head, Department of Entrepreneurship Studies,Madurai Kamaraj University, Madurai - 625021
}

\begin{abstract}
Balance in work and family life is an emerging challenge for both employees and employers. This conceptual paper on WLB gives a framework on the meaning and importance of WLB in current scenario. It throws light on the effects of poor WLB and also gives suggestions to overcome those obstacles. Also views on $W L B$ by both the organization and the employees are highlighted in this paper. This pays way for the reader to have an in-depth knowledge about the necessity of balancing one's own work life and personal life and there by gives opportunities to bring out further research on this topic.
\end{abstract}

Keywords: Work-Life Balance;WLB in India; Work Life Balance; WLB; Organization; Family; Policies; Management;

\section{Introduction}

The term "WORK-LIFE BALANCE (WLB)" was coined in 1986, although its usage in everyday language was being made for a number of years. Interestingly, work/life programs existed as early as the 1930s. The policies and procedures established by an organization with the goal to enable employees to efficiently do their jobs and at the same time provide flexibility to handle personal concerns or problems at their family front In fact; dual-wage-earning families in general are working longer hours. A balance work and life is supposed to exist when there is a proper functioning at work and at home with a minimum of role conflict. Therefore, the incompatibility between the demands from the work and non-work domain give rise to conflict and consequently, people experience a lack of WLB. There is confirmation of the fact that people entering the workforce today are laying emphasis on the importance of WLB more than their predecessors. In spite of this, the extent to which this balance is being achieved is far less than what is desired. In fact, researches bring to mind that graduates are being drawn into situations where they have to work for progressively longer hours and so experience an increasingly unsatisfactory balance between home life and work-life.

\section{What Does Work-Life Balance Really Mean?}

Wehavea work life. Wehavea home life. Andwehave, inallprobability, forgottenhowtokeepthemseparate. Climbing the organizational ladder often requires employees to work long hours and deal with difficult and complex issues. Some days on the job are likely fun and positive and other days are tension-filled and stressful. A common dilemma for many people is how they manage all of the competing demands in work and life and avoid letting any negative effects of work spill over into their personal lives. Research has in fact shown that employees who believe they do not have time for the personal life feel drained and distracted while they are at work. In addition, the spillover of negative aspect of work into an employee's personal life can lead to job exhaustion, disruption of relationships with family and friends, loss of enjoyment, and increased stress. Work-life balance is about creating and maintaining supportive and healthy work environments, which will enable employees to have balance between work and personal responsibilities and thus strengthen employee loyalty and productivity. Numerous studies have been conducted on work-life balance. According to a major Canadian study conducted by Lowe (2005), 1 in 4 employees experience high levels of conflict between work and family, based on work-to-family interference and caregiver strain. If role overload is included, then close to 60 percent of employees surveyed experience work-family conflict. However, some people appear to manage career success and a positive private life with ease.

\section{Work-Life Balance Definition}

Experts say there is no single definition and some don't even like to use the phrase. But generally they agree work-life balance translates to satisfaction with one's entire life -- professional and personal -- and it can be reached even while working long hours. Let's first define what work-life balance is not:

1. Work-Life Balance does not mean an equal balance. Trying to schedule an equal number of hours for each of your various work and personal activities is usually unrewarding and unrealistic. Life is and should be more fluid than that. 
2. Your best individual work-life balance will vary over time, often on a daily basis. The right balance for you today will probably be different for you tomorrow. The right balances for you when you are single will be different when you marry, or if you have children; when you start a new career versus when you are nearing retirement.

3. There is no perfect, one-size fits all, balance you should be striving for. The best work-life balance is different for each of us because we all have different priorities and different lives.

However, WLB is defined as - "The amount of time you spend doing your job compared with the amount of timeyou spend with your family and doing things you enjoy." It can be difficult to get the right work-life balance. Experts say success lies not only in carefully defining how you want to spend your time, but in making sure you adjust your life and work as your needs change. Sometimes even small changes can make a difference. An unmanageable schedule and out-of-control home life can lead to depression, poor performance at work, and conflict with family and a feeling of burnout that can lead physicians to question whether to stay in medicine at all. WLB is a comfortable state of equilibrium achieved between an employee's primary priorities of their employment position and their private lifestyle. Most psychologists would agree that the demands of an employee's career should not overwhelm the individual's ability to enjoy a satisfying personal life outside of the business environment.

\section{WLB: Men Vs. Women}

The past 20 years have seen extraordinary changes in our workplaces and families. Women have entered the workforce in unprecedented numbers and improved their earnings relative to men. At the same time, men have begun to share women's traditional family roles and men and women have both increased the time they spend with children. But even as men spend more time with their kids, the challenges of balancing a career and parenting duties are taking their toll. According to a study by the Families and Work Institute, three out of five men reported some or a lot of stress related to workplace-family life balance-about $25 \%$ more than in the late 1970s. (For women the numbers have stayed virtually the same, at around 45\%) Our workplace policies have not caught up with these new realities. We still behave as though it is the primary job of men to be breadwinners, and the primary job of women to be homemakers and caretakers of children and the elderly. Companies and other organizations that want to continue to attract and retain superior talent-men as well as women-need to develop policies that allow their employees to be successful both at home and at work. The suggestion that work-life balance is a women's issue not only serves as a gross generalization that harms the image of otherwise hard-working, driven women - it's also untrue.

Another study released by the Families and Work Institute, called "The New Male Mystique" found that men experience more work-family conflict than women. "Men are experiencing what women experienced when they first entered the workforce in record numbers - the pressure to 'do it all in order to have it all'," the research showed. Thus WLB is considered to be an important issue to be handled by both men and women of today's busy world.

\section{The Importance Of Work-Life Balance}

Technology has improved people's lives in many different ways. People can live longer, healthier lives because of technological advancements. A student can access vast resources of information to complete assignments and a mother can see and talk to a daughter that is thousands of miles away. The advancements in the way people access information, communicate with one another, and complete tasks have allowed for flexibility in the workplace. It has also created a lack of distinction between work and family time. It is important to draw a distinction between work and life.

People who are constantly tied to their jobs deal with the symptoms of stress and burnout. If a person doesn't have a time to relax and recharge, their ability to do their job decreases and their performance level suffers. Thus, from a management point of view, it is important to encourage a person to take time off from work instead of putting in long hours. Creating a schedule that allows a person to do activities they enjoy will help them to be better employees, friends, and family members. Once the time to work is over the person needs to learn to walk away from the laptop and not answer the cell phone for work calls. This type of balance is not easy to achieve because there will always be people who want to make demands on an individual's time. People need to learn that it is okay to say no and only agree to take on additional tasks if they are important.

Without creating a work-life balance a person isn't able to take time to enjoy the life they have worked so hard to create. They aren't available for friends and family members, and often take their stress out on the ones they love. They can also suffer from illness and physical disorders that stem from prolonged stress such as heart disease, alcoholism, and even diabetes.

${ }^{1}$ Definition of work-life balance noun from the Cambridge Advanced Learner's Dictionary \& Thesaurus $\subset$ Cambridge University Press 


\section{The Negative Effects Of Work Life Conflict}

Long work hours and highly stressful jobs not only hamper employees' ability to harmonize work and family life but also are associated with health risks, such as increased smoking and alcohol consumption, weight gain and depression. Work life conflict has been associated with numerous physical and mental health implications. According to a 2007 study by Duxbury and Higgins, women are more likely than men to report high levels of role overload and caregiver strain. This is because women devote more hours per week than men to non-work activities such as childcare, elder care and are more likely to have primary responsibility for unpaid labor such as domestic work. Furthermore, other studies show that women also experience less spousal support for their careers than their male counterparts. Although women report higher levels of work-family conflict than do men, the numbers of work-life conflict reported by men is increasing. Work-life conflict has negative implications on family life.

According to the 2007 study by Duxbury and Higgins, 1 in 4 Canadians report that their work responsibilities interfere with their ability to fulfill their responsibilities at home. Employees, especially the younger generation who are faced with long hours, the expectations of 24/7 connection and increasing pressure of globalization are beginning to demand changes from their employers. Also, people in the elderly employee segment are working longer now than in the past and are demanding different work arrangements to accommodate their life style needs.In one survey of physicians, control over work schedule was the greater predictor of reported work-life balance. ${ }^{2}$ Demographic and work-life factors, in order of how strongly they affect work-life balance:

- Control over schedule and hours worked

- Total weekly hours worked

- Number of children at home

- Total weekly hours "on call"

- Age

- Gender

- Income

\section{How To Implement A Work-Life Balance Strategy}

Before embarking on a work-life balance strategy it is essential to identify the core needs of the business, for example, some services like a help desk may require a staff presence between certain hours. It is important and useful to consult with staff at this stage in order to get their views. Remember that it is often the staff doing certain jobs that can come up with the most innovative ideas for improvement. From this point it will be necessary to review existing policies and develop a draft work-life balance strategy. This should be put out to consultation to staff and staff groups if appropriate and it may also be worthwhile running a pilot of the policy. After a final review the strategy can be formally launched to all staff. Remember to include a section in the strategy for review and evaluation in order that the uptake and effectiveness can be reviewed over time.

\section{What Can The Organization Do?}

1. Promote work-life flexibility options for all staff. Use examples and case studies as part of in-house promotional materials to show success stories at all levels of the organizations.

2. Demonstrate a willingness to explore ways in which senior roles can be re-designed to accommodate greater flexibility in where and when work is done.

3. Focus on outcomes rather than time spent in the office. Shift thinking away from thinking that presence equals professionalism and performance.

4. Establish a formal process for requesting a flexible work arrangement that is monitored by the HR or Diversity Manager. This should ensure that all staff has an equal opportunity to have their needs reviewed fairly and objectively.

5. As part of their regular performance discussions ask the question "what can I do to support you achieve your work-life balance, what barriers need to be removed or challenged?" Ensure that they take action on the requests.

6. Help executives assess low value work and review workloads and work practices so that that reduces the amount of time they have to spend on non-essential work, or work which can be delegated to others.

7. Include questions about work/life issues and access to senior roles as part of the regular employee consultation/survey process. Take action on the findings.

\footnotetext{
${ }^{2}$ "Predictors of Physician Career Satisfaction, Work-Life Balance, and Burnout,"Obstetrics \& Gynecology, April 2007 (ink)
} 
The key to addressing the concern of losing control is to educate and skill managers to manage performance and flexibility within their work teams. Barbara Holmes, Director of Managing Work-Life Balance International, identifies specific actions that organizations can take to address this issue. She says that the "managerial skills that create organizational effectiveness are the same skills critical to managing a diverse and flexible workforce." These skills include:

a. The ability to define and agree the work to be done and the standards that need to be achieved.

b. Implementing systems and processes that allow the employee to work effectively and productively whether that is from the corporate office or another location.

c. Communicating explicitly about standards for quality and on-time delivery.

d. Creating an environment where employees communicate their concerns and creative ideas.

e. Evaluating and monitoring progress, and being able to modify systems where needed.

f. Providing regular feedback and coaching on performance.

\section{What Does The Organization Need To Do?}

1. Facilitate education programs that up-skill supervisors to manage work/life/flexibility issues within their teams. Such sessions would include information about:

- The business benefits of work/life options and flexible working.

- Managing the performance and output of employees who work flexibly. This should also include management of poor performance (sometimes this is blamed on the flexible work arrangement and avoids dealing with the real issues of performance.)

- Building trust between the employee and manager

- Establishing clear communication channels between the manager, employee and team members so as to avoid crisis situations and resentment between team members. This type of training needs to be practical and include case studies and skill development exercise.

2. Provide one-on-one coaching for managers as they respond to requests for flexible working. This can be done by either a senior manager or a member of the HR team. They can work with the manager to ensure that:

- Clear performance indicators are discussed and established as part of the flexible work arrangement.

- The days, times, location and work hours of any arrangement are clearly established. This is particularly important where an employee is working from home.

- Both parties agree what success will look like and how it will be measured. managed

- How communications between the employee/manager/client/customer and colleagues will be

- Dates and times are agreed when the manager and employee will meet to discuss the effectiveness of the flexible work arrangement.

3. Have clearly defined policies and procedures for flexible work arrangements. These should describe which options are available, which may access them and the criteria that will be used to asses an employee's application to work flexibly. This then provides a level playing field for all employees which give guidance to managers who may be reluctant to relinquish control by allowing employees to work flexibly.

4. Communicate success stories. Experience within best practice organizations would suggest that sharing success stories from within the organization helps managers to recognize that change is possible and that there are bottom line benefits that can be gained from trusting employees and being proactive in the way they manage work/life flexibility issues within their teams.

Some vital work suggestions:

\section{What Can The Employee Do?}

$>$ We have to define some integral elements about work and life for to set an appropriate time-frame. In normal fashion, work is defined for eight hour a day, while one must care about

$>$ In all sort of work we have to deal with meetings and assignments which need to be accomplish with in suitable time to avoid next day burden.

$>$ In taking care about assigned work, follow-ups and dealing with people, there needs a well-organized attitude in friendly manner.

$>$ One must set a priority list of daily work and also need to get a pause along it to get ready for the next.

$>$ There is another important issue during work as to deal with rush a calm and soft attitude supposed to excellent in finding best results.

$>$ All the co-worker also needs your attention during your duty hours and there needs an excellent attitude is important while always keep friendly way of dealings required. 
$>$ Sometimes we don't need anything or want to leave it, so during work we have to take care about the issues which can effect on up-coming events, so its batter take pause along the work.

\section{Some vital Life suggestions:}

$>$ People need to give proper time to their interest because this necessary to refresh and overcome the mental as well as physical stress.

$>$ Morning walk or a long walk in the afternoon is tonic for the people who stay all the day with sitting-work/ office-work. They also needs to go for exercise or any play ground game which keeps their health best and energize them well.

$>$ The people whose wok nature is a bit different and not stay in office needs to adopt hobby of reading or indoor games which will be a refreshing tonic for mind and body.

$>$ Always give time to spouse, children, parents, relatives and friends even your home-workers according to your available time and it's also necessary to adopt any community for your interest to acquaint with vicinity changes.

$>$ A home even a family activities place but there needs to be setup some cheerful activities like birthday celebration, get-together parties, family friend's gatherings etc., which is necessary to be an active part of society.A pause in work and proper deep-sleep in the night according to age and nature of work is an essential element of work-life balance.

$>$ Your soul will be thirsty in all this work-life management if you don't care about that. Health, wealth, joy even any big achievement sometimes felt nothing only due to the ignoring the spiritual activities. Yourself, your inner will be in worry if you'll not give time to your soul, that's a pray, a religious activity, a meditation which returns a bliss in your life, a calm state of mind, a physical healing, a boost to your immune system.

$>$ All our work-life happenings centered to only one nucleus, God/Allah/ Creator whatever name you like to call him, always empower us even most of the time we don't bother that. We need to stay in front of our creator as prays at once, twice or more times a days to find everlasting bliss, rejoice the inner, to calm down the mind, to dissolve negative thoughts, to get inspired for all the work-life activities.

\section{Conclusion}

Love and work are said to be the cornerstones of being human and both are very important for happiness. Yet juggling the demands of each can be difficult. By thinking differently, we can perhaps find ways to have a better balance between work and home. Evidence suggests that improvements in people management practices, especially work time and work location flexibility, and the development of supportive managers, contribute to increased work-life balance. Work-life balance programs have been demonstrated to have an impact on employees in terms of recruitment, retention/turnover, commitment and satisfaction, absenteeism, productivity and accident rates. Companies that have implemented work-life balance programs recognize that employee welfare affects the "bottom line" of the business. Parameters are required to ensure that programs are having the desired effect on both employees and the company. Six parameters that can be used to evaluate work life balance programs are: extent of management buy-in and training, how programs are communicated to employees, corporate culture, management controls, human resources policies and employee control. Finally, self-management is important; people need to control their own behavior and expectations regarding work-life balance. We may not develop Gandhian levels of courage immediately, but surely we can do better than having to look back on our lives and regret that we lived by someone else's priorities.

\section{References}

[1] http://www.worklifebalance.com/worklifebalancedefined.html

[2] http://www.bia.ca/articles/AReportontheImportanceofWork-LifeBalance.htm

[3] http://www.womentomorrow.com/wotoblog/Is-Work-Life-Balance-a-Women-s-Issue_a27.html

[4] http://www.theguardian.com/commentisfree/2013/aug/08/women-opting-back-in-workforce

[5] https://www.boundless.com/management/human-resource-management--2/current-topics-in-human-resource-management/growingimportance-of-work-life-balance/

[6] http://www.wikihow.com/Maintain-a-Work-Life-Balance

[7] http://www.actionforhappiness.org/take-action/get-a-good-balance-between-work-and-life

[8] http://www.businessdictionary.com/definition/work-life-balance.html\#ixzz2f8Mdvs82

[9] http://www.communitybusiness.org/images/cb/publications/2011/WLBGuide2011.pdf 